\title{
Peptik ülserli hastalarda iskemi modifiye albumin düzeyleri
}

\author{
Ischemia-modified albumin levels in patients with peptic ulcer
}

\author{
Evrim KAHRAMANOĞLU AKSOY ${ }^{1}$, Ferdane SAPMAZ', Özlem DOĞAN², Özgür ALBUZ ${ }^{3}$, Metin UZMAN \\ Keçiören Eğitim ve Araştırma Hastanesi, 'Gastroenteroloji Bölümü, ${ }^{3}$ Genel Cerrahi Kliniği, Ankara \\ Ankara Üniversitesi Tıp Fakültesi, ${ }^{2}$ Tıbbi Biyokimya Ana Bilim Dalı, Ankara
}

\begin{abstract}
Giriş ve Amaç: İskemi modifiye albümin; iskemi ve oksidatif stresin değerlendirilmesinde yeni kullanılmaya başlanan bir belirteçtir. Bu çalısmanın amacı peptik ülser hastalarında tedavi öncesi ve sonrası serum iskemi modifiye albümin değerlerini ölçmek, iskemi modifiye albümin/ albümin oranını hesaplamak ve kontrol grubuyla karşılaştırmaktır. Gereç ve Yöntem: Çalışmaya Kasım 2016-Nisan 2017 tarihleri arasında Keçiören Eğitim ve Araştırma Hastanesi Gastroenteroloji Kliniğinde herhangi bir nedenle üst gastrointestinal sistem endoskopisi yapılmış ve peptik ülser saptanmış 32 hasta ve 28 sağlıklı kontrol dahil edildi. Biyopsi sonucu Helicobacter pylori saptanan hastalara eradikasyon tedavisi başlanırken, saptanmayanlara antisekretuvar tedavi verildi. Hastaların ve kontrol grubunun tedavi öncesi ve tedavi sonrası iskemi modifiye albümin değerleri spektrofotometrik olarak ölçüldü, iskemi modifiye albümin/albümin oranları hesaplandı. Bulgular: Hastalar ve kontrol grubu arasında yaş ve cinsiyet dağılımı açısından istatistiksel olarak anlamlı fark yoktu. Peptik ülser hastalarının tedavi öncesi ortalama iskemi modifiye albümin değeri $0.19 \pm 0.49$ absorbans unit, ortalama iskemi modifiye albümin/albümin oranı $0.42 \pm 0.11$, kontrol grubunun ortalama iskemi modifiye albümin değeri $0.45 \pm 0.16$ absorbans unit, iskemi modifiye albümin/albümin $0.11 \pm 0.40$ olarak hesaplandı. Aradaki fark istatistiksel olarak anlamlı idi $(p<0.0001)$. Tedavi sonrası iskemi modifiye albümin $0.20 \pm 0.72$ absorbans unit, iskemi modifiye albümin/albümin oranı $0.45 \pm 0.17$ olarak hesaplandı. Tedavi sonrası değerler kontrol grubu ile karşılaştııılığında aradaki fark istatistiksel olarak anlamlı idi $(p<0.0001)$. Tedavi öncesi ve sonrası değerleri kendi içinde karşılaştırıldığında aradaki farkın istatistiksel olarak anlamlı olmadığı saptandı. Sonuç: Peptik ülserli hastalarda tedavi sonrasında da oksidatif stres belirteci olan iskemi modifiye albümin değeri ve iskemi modifiye albümin/ albümin yüksek seyretmektedir.
\end{abstract}

Anahtar kelimeler: Iskemi modifiye albumin, peptik ülser
Background and Aims: Ischemia-modified albumin is a recently introduced marker in the evaluation of ischemia and oxidative stress. The aims of this study are to measure serum levels of ischemia-modified albumin before and after treatment in patients with peptic ulcer disease, to calculate the ischemia-modified albumin to albumin ratio, and to compare these values to those from the control group. Materials and Methods: Between November 2016 and April 2017, 32 patients who underwent upper gastrointestinal system endoscopy for any reason, and were found to have peptic ulcers were included in the study, along with 28 healthy controls. Some patients who had Helicobacter pylori as a result of biopsy recieved eradication therapy, while others were treated with antisecretory therapy. Ischemia-modified albumin levels in both the patient and control groups before and after treatment were measured spectrophotometrically, and ischemia-modified albumin to albumin ratios were calculated. Results: There was no statistically significant difference observed in the age and sex distributions between the patient and control groups. The mean ischemia-modified albumin value in the peptic ulcer patient group was $0.19 \pm 0.49$ absorbance units, and the mean ischemia-modified albumin to albumin ratio was $0.42 \pm 0.11$. The mean ischemia-modified albumin value in the control group was $0.45 \pm 0.16$ absorbance units, and the mean ischemia-modified albumin to albumin ratio was $0.11 \pm 0.40$. The difference was statistically significant $(p<0.0001)$. After treatment in the peptic ulcer patient group, ischemia-modified albumin level was $0.20 \pm 0.72$ absorbance units and ischemia-modified albumin to albumin ratio as $0.45 \pm 0.17$. When the post-treatment values were compared with values from the control group, the difference was statistically significant $(p<0.0001)$. When pre-treatment values were compared to post-treatment values, statistically significant difference was not observed. Conclusion: Ischemia-modified albumin level and ischemia-modified albumin to albumin ratio, both indicators of oxidative stress, are elevated in patients with peptic ulcer post-treatment.

Key words: Ischemia-modified albumin, peptic ulcer

Peptik ülser dünyadaki en yaygın hastalıklar arasındadır ve multiple etiyolojik bir patogeneze sahiptir. Normal gastrik ve duodenal mukoza, mukus sekresyonu yoluyla asit ve pepsinin etkisinden korunur (2). Bikarbonat üreterek fazla asidin kan yolu ile taşınmasını, epitelyum hücre yaralanmasının onarımını ve hızla yenilenmesini sağlar.

\footnotetext{
Iletişim: Ferdane SAPMAZ

Keçiören Eğitim ve Araştırma Hastanesi Gastroenteroloji Bilim Dalı, Ankara Tel: +903123569017

E-mail: ferda-sapmaz@hotmail.com
}

Geliş Tarihi: 25.01.2018 • Kabul Tarihi: 08.06.2018

DOI: 10.17941/agd.462657 
Hayvan deneyleri iskemik modellerinde peptik ülser oluşumu sağlanabilmiştir (3). Gastrik iskemi ile birlikte gastrointestinal hipoperfüzyon, oksidatif hasar, safra tuzları ve pankreatik enzimlerin reflüsü, mikrobiyal kolonizasyon ve mukozal bariyer değişiklerini kapsamaktadır (4). Gerçek mekanizmalar tam olarak bilinmemesine karşın iskeminin önemli bir predispozan faktör olduğuna inanılmaktadır ve antioksidan bileşiklerin kullanılması umut vericidir.

İskemi modifiye albümin (IMA); iskemi ve oksidatif stresin değerlendirilmesinde yeni kullanılmaya başlanan bir belirteçdir. Bu çalışmanın amacı peptik ülser hastalarında tedavi öncesi ve sonrası serum IMA değerlerini ölçmek, iMA/albümin oranını hesaplamak ve kontrol grubuyla karşılaştırmaktır.

\section{GEREÇ ve YÖNTEM}

Çalışmaya Kasım 2016-Nisan 2017 tarihleri arasında Keçiören Eğitim ve Araştırma Hastanesi Gastroenteroloji Kliniğinde herhangi bir nedenle üst gastrointestinal sistem endoskopisi yapılmış ve peptik ülser saptanmış 32 hasta ve 28 sağlıklı kontrol dahil edildi. Biyopsi sonucu Helicobacter pylori ( $H$. pylori) saptanan hastalara eradikasyon tedavisi başlanırken, saptanmayanlara antisekretuvar tedavi verildi. Hastaların ve kontrol grubunun tedavi öncesi ve tedavi sonrası IMA değerleri spektrofotometrik olarak ölçüldü, IMA/albümin oranları hesaplandı. Hastaların tedavi öncesi ve tedavi sonrası IMA, IMA \albümin, demir, total protein oranları değerlendirildi. Ayrıca yaş ve cinsiyet olarak benzer özellikte olan kontrol grubunun IMA, IMA albümin, albümin, demir, total protein değerleri tedavi öncesi ve tedavi sonrası değerleri ile kıyaslandı. Çalışma verilerinin analizleri IBM SPSS 22.0 paket programı kullanılarak yapıldı. Kategorik değişkenler total popülasyona göre oran ve yüzde olarak değerlendirildi.

Sürekli değişkenler ortalama ve standart sapma olarak değerlendirildi. Değişkenlerin dağılımı Kolmogorov Smirnov dağılım testi ile değerlendirildi. Gruplar arası oranlar $X^{2}$ or Fisher exact testiyle değerlendirildi. Bağımsız iki grup arası sürekli değişkenler arasında normal dağılımda olanlarda; bağımsız gruplarda student t-testi, normal dağılıma uymayan değişkenlerde Mann Whitney $U$ testi kullanılmıştır. Bağımlı gruplar arası sürekli değişkenlerin kıyasında normal dağılımda olanlarda bağımlı gruplarda student t-test, normal dağılımda olmayan sürekli değişkenler için Wilcoxon rank testi uygulanmıştır.

\section{BULGULAR}

Çalışmaya toplam 60 olgu (32 hasta, 28 kontrol) dahil edildi. Hastalar ve kontrol grubu arasında yaş ve cinsiyet dağılımı açısından istatistiksel olarak anlamlı fark yoktu (Tablo 1). Peptik ülser hastalarının tedavi öncesi ortalama

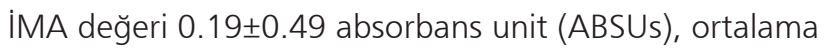
iMA/albümin oranı $0.42 \pm 0.11$, kontrol grubunun ortalama iMA değeri $0.45 \pm 0.16$ ABSUs, iMA/albümin 0.11 \pm 0.40 olarak hesaplandı (Tablo 2). Aradaki fark istatistiksel olarak anlamlı idi ( $p<0.0001)$. Tedavi sonrası IMA $0.20 \pm 0.72$ ABSUs, IMA/albümin oranı $0.45 \pm 0.17$ olarak hesaplandı (Tablo 3). Tedavi sonrası değerler kontrol grubu ile karşılaştırıldığında aradaki fark istatistiksel olarak anlamlı idi ( $p<0.0001)$. Tedavi öncesi ve sonrası değerleri kendi içinde karşılaştırıldığında aradaki farkın istatistiksel olarak anlamlı olmadığı saptandı (Tablo 4).

Tablo 1. Demografik değişkenler

\begin{tabular}{|l|c|c|c|c|}
\hline & Yaş & P & Cinsiyet & P \\
\hline Mide ülserli hasta grubu & $42.51 \pm 2.43$ & \multirow{2}{*}{0.107} & 22 erkek $\backslash 10$ kadın & 0.941 \\
\hline Kontrol grubu & $35.52 \pm 3.02$ & & 19 erkek $\backslash 9$ kadın & \\
\hline
\end{tabular}

Tablo 2. Mide ülserli hasta grubu ile kontrol grubunun karşılaştırılması

\begin{tabular}{|lcccccc} 
& IMA & IMA\ALB & ALB & Protein & Demir \\
\hline Mide ülserli hasta grubu (tedavi öncesi) & $0.19 \pm 0.49$ & $0.42 \pm 0.11$ & $4.57 \pm 0.39$ & $7.41 \pm 0.56$ & $99.22 \pm 65.91$ \\
\hline Kontrol grubu & $0.45 \pm 0.16$ & $0.11 \pm 0.40$ & $4.29 \pm 9.28$ & $7.25 \pm 1.47$ & $76.35 \pm 25.75$ \\
\hline
\end{tabular}

IMA: Iskemi modifiye albümin. ALB: Albümin 
Tablo 3. Tedavi sonrası mide ülserli hasta grubu ile kontrol grubunun karşılaştırılması

\begin{tabular}{|lccccc}
\hline & IMA & IMA \ALB & ALB & Protein & Demir \\
\hline Mide ülserli hasta grubu (tedavi sonrası) & 0.000 & 0.000 & 0.001 & $P=0.846$ & $P=0.110$ \\
\hline Kontrol grubu & $0.20 \pm 0.72$ & $0.456 \pm 0.17$ & $4.56 \pm 0.27$ & $7.43 \pm 0.42$ & $110.49 \pm 90.30$ \\
\hline
\end{tabular}

IMA: İskemi modifiye albümin. ALB: Albümin

Tablo 4. Mide ülserli hastaların tedavi öncesi ve tedavi sonrası değerlerinin kıyası

\begin{tabular}{|lcccccc} 
& IMA & IMA \ALB & ALB & Protein & Demir \\
\hline Mide ülserli hasta grubu (tedavi öncesi) & $0.19 \pm 0.49$ & $0.42 \pm 0.11$ & $4.57 \pm 0.39$ & $7.41 \pm 0.56$ & $99.22 \pm 65.91$ \\
\hline Mide ülserli hasta grubu (tedavi sonrası) & $0.20 \pm 0.72$ & $0.456 \pm 0.17$ & $4.56 \pm 0.27$ & $7.43 \pm 0.42$ & $110.49 \pm 90.30$ \\
\hline
\end{tabular}

imA: İskemi modifiye albümin. ALB: Albümin

\section{TARTISSMA}

Peptik ülser, asid ve pepsinin etkileri nedeni ile duodenum mukozasında oluşan, muskularis propriayı geçen belirgin destrüksiyon oluşmasıdır (5). Temelde agresif faktörler (asid, pepsin) ile defansif faktörler (mukus, bikarbonat sekresyonu, mide epitel hücrelerinin bütünlüğü, yenilenmesi ve kanlanması) arasındaki denge kaybı nedeni ile geliştiği düşünülmektedir (6). Son yıllarda kaydedilen gelişmelere rağmen bugün hala ülser patogenezinde açıklanmamış sorular bulunmaktadır.

Bir oksidatif stres ürünü olan IMA; albümin yapısındaki son amino terminali, kobalt, bakır ve nikel gibi transisyon metallerinin bağlandığı bölgedir (7). İskemi durumunda ortaya çıkan hipoksi, asidoz, serbest radikal hasarı ve membran bozulması gibi nedenler bu transisyon metallarinin albüminin N-terminaline bağlanmalarını azaltır. Yapısında değişiklik meydana gelmiş olan bu albümine iskemik modifiye albümin denir $(8,9)$. Son ylllarda yapılan çalışmalarda kardiyak iskemi belirteci olarak çalışlan iMA'nın farkı patolojilerde de artabileceği gösterilmiştir (10).

Yine mide iskemisi ve/veya iskemi reperfüzyonun ülser oluşumuna neden olduğu bilinmektedir. Serbest radikaller, özellikle antioksidanlarla dengelenmediği durumlarda peptik ülser patogenezi ile sonuçlanabileceği bildirilmiştir (11).
Çalışmamızda peptik ülser hastalarının tedavi öncesi ortalama IMA değeri, absorbans unit (ABSUs), ortalama iMA/albümin oranı ile kontrol grubunun ortalama IMA değeri, ABSUs, IMA/albümin değerleri arasında istatistiksel olarak anlamlı fark bulunmakta idi $(p<0.0001)$. Ayrıca tedavi sonrasında ülserli hasta grubunda halen mevcut değerlerin anlamlı oranda farklı oldukları saptandı. Bu durum peptik ülserli hastalarda iskeminin etkili olabileceğini düşündürdü.

Mide ülseri olan hasta grubunda tedavi öncesi ve sonrası IMA, albümin, IMA \albümin, demir ve protein değerleri açııından arada herhangi fark bulunamamıştır. Bu durum ülserli hastalarda iskeminin, peptik ülser tekrarlarına eğilim yaratabileceğini düşündürmüş, ancak çalışmanın dizaynı takip içermediğinden net yorumlanamamış, bu konu ile ilgili literatürden de bilgi elde edilememiştir.

Sonuç olarak peptik ülserli hastalarda tedavi sonrasında da oksidatif stres belirteci olan IMA değeri ve IMA/ albümin yüksek seyretmektedir. Bu durumun literatür ile uyumlu olarak peptik ülser patogenezinde iskemi ve buna sekonder gelişen oksidatif strese bağlı olduğu düşünüldü. Patogenez hakkında daha net bilgi sahibi olabailmek için bu konuda yapılacak daha kapsamlı çalışmalara gereksinim vardır. 


\section{KAYNAKLAR}

1. Sbarouni E, Georgiadou P, Voudris V. Ischemia modified albumin changes - review and clinical implications. Clin Chem Lab Med 2011;49:177-84.

2. Szabo S. Gastroduodenal mucosal injury-acute and chonic: Pathways, mediators, and mechanism. J Clin Gastroenterol 1991;13(Suppl)1:S1-8.

3. Aykaç G, Uysal M, Yalçın AS, et al. The effects of chronic ethanol ingestion on hepatic lipid peroxide, glutathione, glutathione peroxidase and glutathione transferase in rats. Toxicology 1985;36:71-6.

4. Calatayud S, Barrachina D, Esplugues J. Nitric oxide: Relation to integrity, injury, and healing of the gastric mucosa. Mic Res Technique 2001;53:325-35.

5. Abe $\mathrm{S}$, Sasano $\mathrm{H}$, Katoh $\mathrm{K}$, et al. Immunohistochemical studies on EGF family growth factors in normal and ulcerated human gastric mucosa. Dig Dis Sci 1997;42:1199-209.

6. Kwiencien S, Brzozowski T, Konturek PC, Konturek SJ. The role of reactive oxygen species in action of nitric oxide-donors on stress-induced gastric mucosal lesions. J Physiol Pharmacol 2002;53:76173.
7. Özdem S, Çete $Y$, Dönmez L, et al. Serum levels of ischemia-modified albumin (IMA) in healthy adults and patients with acute coronary syndrome. Turkr J Emerg Med 2005;5:169-74.

8. Zurawska-Plaksej E, Grzebyk E, Marciniak D, et al. Oxidatively modified forms of albumin in patients with risk factors of metabolic syndrome. J Endocrinol Invest 2014;37:819-27.

9. Fidan $E$, Menteşe $A$, Kavgacı $H$, et al. Increased ischemia-modified albumin levels in patients with gastric cancer. Neoplasma 2012;59:393-7.

10. Ellidag HY, Eren E, Aydin O, et al. Ischemia modified albumin levels and oxidative stress in patients with bladder cancer. Asian Pac J Cancer Prev 2013;14:2759-63.

11. Konturek PC. Physiological, immunohistochemical and molecular aspects gastric adaptation to stress, aspirin and to $\mathrm{H}$. pylori-derived gastrotoxins. J Physiol Pharmacol 1997;48:3-42. 